\title{
Картирование локусов ответственных за содержание токоферолов в семенах подсолнечника с использованием высокопроизводительного генотипирования
}

Губаев Р.Ф. ${ }^{l}$, аспирант; Чернова А.И. ${ }^{1}$, аспирант; Болдырев С.В. ${ }^{l}$, м.н.с.; Мартынова Е.У. ${ }^{1}$, к.б.н., м.н.с.; Коваленко Т.А. ${ }^{2}$, аспирант; Горюнова С.В. ${ }^{l}$, к.б.н., н.с.; Хайтович Ф.Е. ${ }^{l}$, Ph.D., профессор; Демурин Я.Н. ${ }^{2}$, д.б.н., зав. отделом биологических исследований.

${ }^{1}$ Сколковский институт науки и технологий, Москва, Россия;

${ }^{2}$ Всероссийский научно-исследовательский институт масличных культур имени В.С. Пустовойта, Краснодар, Россия.

*e-mail:rim.gubaev@skoltech.ru

Подсолнечник является важнейшей масличной культурой в России. Одним из ключевых фенотипических признаков подсолнечника - служит содержание в масле различных классов токоферолов, которые проявляют антиоксидантную активность, а также активность витамина E. B настоящем исследовании было проведено ассочиативное картирование локусов, сиепленных $c$ содержанием токоферолов $c$ применением современных подходов выскокопроизводительного генотипирования $u$ биоинформатического анализа. Полученная информация будет в дальнейшем использована для создания маркер-опосредованной схемы селекиии по составу токоферолов с использованием полученных маркеров.

Ключевые слова: подсолнечник, картирование локусов количественных признаков, токофероль, маркер-опосредованная селекиия.

\section{Association mapping of loci responsible for tocopherol composition in sunflower seeds using high-throughput genotyping}

Gubaev R.F. ${ }^{1 *}$, Chernova A.I. ${ }^{1}$, Boldyrev S.V. ${ }^{l}$, Martynova E.U. ${ }^{l}$, Kovalenko T.A. ${ }^{2}$, Goryunova S.V. ${ }^{l}$, Khaitovich F.E. ${ }^{l}$, Demurin Y.N. ${ }^{2}$.

${ }^{1}$ Skolkovo Institute of Science and Technology, Moscow, Russia;

${ }^{2}$ Federal scientific center "V.S. Pustovoit All-Russian Research Institute of Oil crops", Krasnodar, Russia.

*e-mail:rim.gubaev@skoltech.ru

Sunflower is the most important oilseed crop in Russia. One of the key phenotypic trait of sunflower is the composition of tocopherols that exhibit antioxidant activity as well as the vitamin E activity. In the present study, mapping of loci associated with the content of tocopherols was carried out using modern approaches of high-throughput genotyping and bioinformatics analysis. The obtained information will be further used to create a marker-assisted selection 
scheme for the tocopherol composition using the obtained markers.

Key words: sunflower, quantitative trait loci mapping, tocopherols, marker-assisted selection.

Подсолнечник - важнейшая масличная культура, один из основных источников растительных жиров в России, СНГ, Турции и многих других странах. Свойства и область применения растительного масла во многом определяется его химическим составом, который отвечает за пищевую ценность масла и его физические характеристики, например скорость окисления, температуру кипения и другие.

Помимо триглицеридов и жирных кислот в состав подсолнечного масла входяттокоферолы - природные антиоксиданты липофильной природы, обладающее активностью жирорастворимого витамина Е. Токоферольный комплекс подсолнечного масла представлен четырьмя различными формами, а именно $\alpha-, \beta-, \gamma$ - и $\delta$-токоферолами. Активность витамина Е убывает в ряду от $\alpha$ - к $\gamma$-токоферолу, в то время как in vitro антиоксидантные свойства, наоборот, возрастают. С одной стороны, токоферолы как природные антиоксиданты определяют окислительную стабильность масла, препятствуя процессам свободнорадикального окисления липидов, и обеспечивая устойчивость к прогорканию. С другой стороны, показано, что умеренное потребление витамина Е оказывает положительное влияние на здоровье человека. Витамин Е благодаря своими антиоксидантными свойствами и способности нейтрализовать свободные радикалы должен обязательно присутствовать в диете. В связи с вышеперечисенным, получение семян с увеличенным содержанием витамина Е (в первую очередь содержание $\alpha$-токоферола) может позволить производить подсолнечное масло с улучшенными питательными свойствами. Увеличение содержания сильных, в антиоксидантном отношении, форм токоферолов ( $\delta$ и $\gamma$-токоферолы) сделает возможным улучшение качества масла семян подсолнечника. Таким образом, одной из перспективных задач в селекции подсолнечника является получение масла с увеличенным содержанием токоферолов и сбалансированным составом токоферольного комплекса.

В представленной работе было проведено ассоциативное картирование локусов количественных признаков на основе данных высокопроизводительного секвенирования сегрегирующих популяций подсолнечника, различающихся по признаку содержания токоферолов с целью поиска локусов, потенциально ответственных за изменчивость профиля токоферолов. Для этого на первом этапе была проведена фенотипическая характеристика $200 \mathrm{~F}_{2}$ потомков растений, контрастных по содержанию токоферолов. В качестве родителей использовали мутантную 
линию (гамма/дельта-токоферольный фенотип) и линию дикого типа (альфатокоферольный фенотип). Для определения содержания токоферолов была использована технология тонкослойной хроматографии с последующей денсиометрией. При этом было определено относительное содержание $\alpha$-, $\beta$-, $\gamma$ - и $\delta$-токоферолов. Для генотипирования был использован подход генотипирования посредством секвенирования (genotyping-by-sequencing, GBS) на высокопроизводительной платформе Illumina. Такой подход позволяет секвенировать лишь выборочные участки генома, ограниченные специфическими сайтами рестрикции и таким образом сэкономить на объеме секвенирования.

В ходе секвенирования были получены риды, соответствующе фрагментам ДНК, риды были отфильтрованы по качеству и выровнены на референсный геном подсолнечника HanXRQ1. Затем с помощью программы GATK были найдены однонуклеотидные генетические полиморфизмы (SNP). В результате анализа данных генотипирования было получено более 6 тысяч SNP, которые были использованы для построения генетической карты высокой плотности. Построение генетической карты было проведено в программе $\mathrm{R} / \mathrm{qtl}$, для этого была использована информация о расположении локусов на физической карте подсолнечника. Полученная карта была использована при поиске локусов, достоверно ассоциированных c содержанием токоферолов с помощью сложного интервального картирования (composite interval mapping, CIM). Также дополнительно была проведена проверка ассоциированных локусов с помощью смешанных регрессионных моделей.

В результате проведенного анализа были обнаружены локусы на хромосоме 8 , достоверно ассоциированные с содержанием $\alpha$-токоферолов. А также локусы, расположенные на хромосомах 1 и 8 и достоверно ассоциированные с содержанием $\beta$-токоферолов. Информация о найденных локусах и маркирующих их SNP будет использована для построения предсказательных моделей содержания токоферолов на основании генотипа и разработки ПЦР-тестов для маркер-опосредованной селекции подсолнечника.

Благодарности: Работа выполнена при финансовой поддержке РФФИ в рамках научного проекта № 20-316-80002. 